\title{
Additional Certifications For CPA's: A Quality Control Issue
}

Kristofer C. Neslund (E-mail: kneslund@sjfc.edu), St. John Fisher College, USA

Arthur F. Hintz (E-mail: ahintz@sjfc.edu), St. John Fisher College, USA

Michael W. Fedoryshyn (E-mail: mfedoryshyn@sjfc.edu), St. John Fisher College, USA

\begin{abstract}
Over the last twenty years public accounting firms have started to provide additional services other than attest services and tax preparation, such as business valuations and financial planning, which can be very profitable for the firms. However, the Certified Public Accountant (CPA) designation that has been used in many cases to market these services provides no assurance that the accountant is adequately trained in these new fields since CPA certification requires neither knowledge nor experience in these areas. This paper reviews the services being provided by accountants and the additional professional certifications available to help accountants deliver quality services consistent with the public's expectations of CPAs. In addition, firms that may be thinking of expanding into new niche areas can make sure that they hire professionals or train existing staff with the appropriate credentials.
\end{abstract}

\section{Introduction}

There is little doubt that auditing and tax compliance are becoming less significant portions of accounting firms' overall practice. In its Vision Project: 2011 and Beyond, the AICPA found that real revenues from these services had remained constant from the late 1980s into the mid-1990s while revenues from other service areas were increasing. There is little reason to believe that the historical niches of the CPA will not continue to erode, especially with increased pressure from clients to decrease the cost of audit and compliance engagements which many clients view as non-value-added services. Although the audit function may enjoy resurgence in light of the Sarbanes-Oxley Act, the AICPA Vision Project notes that:

"There are tremors shaking the foundation of the accounting profession. ... The increasing complexities of the global environment and the commodity characteristics of traditional services mandate that the CPA profession migrate up the economic value chain. Commodification and technology are challenging the economic viability of the profession. ... Unless the profession is prepared to compete for razor thin profit margins in a world of high volume and mass markets, CPAs will need to adapt to change. The challenge [is] to move the profession toward the ... valued economic base of the future." (AICPA, 2002):

The Vision Project makes clear that CPAs must move up the economic value chain to survive. Among the many implications of this move are the needs for CPAs to: 1) become specialized; and 2) become significantly more market-oriented, both in terms of keeping abreast of changes in the market's perception of what constitutes high value-added services and in terms of undertaking vigorous promotion of those services.

For some time now, public accounting firms have been shifting their mix of services away from the traditional areas toward new, market-oriented services like business valuation and financial planning. While these services have turned out to be quite profitable, the Certified Public Accountant (CPA) designation under which most accountants market the new services provides no assurance that the accountant is competent in the new fields. The CPA's education requirements do not include specialized knowledge in these areas and its experience requirements cover primarily the traditional attest and tax functions. 
How does a firm obtain specialization capable of supporting the delivery of new, high value-added services in a manner that has sufficient rigor and credibility to enhance the public's perception of CPA holders? Some firms may develop their expertise internally, identifying candidates who have an interest in the area and then getting them trained and certified. Other firms may want to hire the expertise necessary to get into this niche and will want to ensure the new hire has the appropriate training and certifications to successfully perform the work and market the engagements. Other firms may find it advantageous to acquire these specializations by entering strategic alliances with CPA firms or non-CPA firms that currently possess appropriate expertise in these areas. Others may wish to add to the breath of their service lines through merger with another accounting firm.

This paper reviews the services being provided by accountants and the certifications available in these areas of specialization. These credentials will help the CPA obtain the skills and competencies that allow migration to high value-added services, market these services in an increasingly competitive marketplace, and ensure that the services are delivered with the high-quality the public expects from a CPA.

The following minimum criteria were established for including a certification in this paper:

- Mandatory examination or other formal assessment

- $\quad$ Mandatory, enforceable adherence to enumerated ethical and professional standards

- $\quad$ Mandatory Continuing Professional Education (CPE)

- Designation in existence at least 2 years (the relative brevity of this criteria is due to the recent interest of accountants in specialization)

Some credentials available to accountants have been omitted because of their extremely specialized nature. Others do not appear because they are so new they lack a record upon which to assess the quality of the credential. However, designations have not been excluded merely because of a low number of holders if the sponsoring organization is well regarded and the requirements for obtaining the credential are rigorous.

A quality credential has an educational component that imparts the set of skills and competencies necessary to deliver a given specialized line of services. It ensures the attainment of the minimum required skills through a formal process of evaluation, typically an examination, but occasionally either by a case study or the assessment of work product. It promotes the maintenance of those abilities through an emphasis on relevant lifelong learning. An enforceable code of professional conduct gives the public confidence that holders will provide quality services with integrity. A reputable credential facilitates marketing by permitting holders to display a unique designation and benefit from the sponsoring organization's efforts to widen the public's recognition and respect for the credential.

A detailed listing of all the certifications identified in this paper, with their sponsoring organizations, requirements for certification, CPE requirements, date of inception, and number of holders can be found in Table 1.

\section{Accounting Designations}

A strong indicator of an individual's commitment to the accounting profession and life-long learning is attainment of one of the following widely recognized certifications; the Certified Public Accountant (CPA), the Certified Management Accountant (CMA), the Certified in Financial Management (CFM), or Certified Internal Auditor (CIA). One or more of these credentials should be obtained early in a professional career before the other specialized credentials are attempted.

The Certified Public Accountant (CPA) designation is the oldest accounting certification and the most widely recognized. The CPA is both a certification and a license and is granted by one of the 50 states, District of Columbia, Guam, Puerto Rico, or the Virgin Islands. The CPA license is required for an individual to provide attest services and also allows a CPA to practice before the Internal Revenue Service. Certification requirements depend on the state, but generally require either a bachelors or a 150-hour degree, passing the uniform CPA exam, and obtaining work experience emphasizing the attest area. In most states continuing professional education is required. 
Individual state requirements can be found at www.nasba.org. Follow the links to the appropriate state Board of Accountancy.

The Institute of Management Accountants sponsors two certifications for private accountants. The Certified Management Accountant (CMA) is for individuals engaged in management accounting and the Certified in Financial Management (CFM) is for individuals engaged in financial management. The certificates both have an education and work experience requirement, require passing a four-part exam and require 30 hours of CPE per year.

The Institute of Internal Auditors offers the Certified Internal Auditor designation (CIA) for individuals who desire a career in internal audit. The designation requires a bachelor's degree; two years of work experience, passing a four-part examination, and 80 hours of CPE every two years.

\section{Business Valuation Designations}

Many accountants think of business valuation in terms of mergers and acquisitions; but profitable niches exist in estate planning, dispute resolution, divorce consultation, bankruptcy proceedings, and litigation support and services.

More recently, Statement of Financial Accounting Standards (SFAS) Nos. 141 and 142, Business Combinations and Goodwill and Other Intangible Assets, require companies to periodically value their intangible assets. Auditors may not currently have the expertise to adequately evaluate the validity of the valuation.

While business valuation is one of the fastest growing and more profitable areas in accounting, potential liabilities exist for failure to provide services with due professional care. This potential liability makes training and certification an essential component for any accountant or firm wishing to practice in this area. In addition, marketing these services in an increasingly competitive environment makes achieving appropriate training and certifications more crucial to the success of the venture. (Gaffen, 2002)

Four organizations offer professional designations in the area of business valuations. Some of these organizations offer different levels of certification, designed to recognize progressively higher levels of professional achievement.

The American Institute of Certified Public Accountants (AICPA) first started offering the Accredited in Business Valuation (ABV) designation in 1997. Designed specifically for CPAs who have completed at least 10 business valuation engagements, this designation provides assurance that these CPAs possess advanced skills and knowledge in this area.

The Institute of Business Appraisers (IBA), which was formed in 1978, sponsors three designations for professionals in different levels of business valuation services. The Certified Business Appraiser (CBA) designation was first offered in 1978 and is available to individuals who have five years of experience as an appraiser or have completed 90 hours of coursework in business valuation. The Master Certified Business Appraiser (MCBA) was added in 1998 and is available only to those individuals who have held the CBA designation for five years and have at least 10 years of business valuation experience. The third designation, Business Valuation Accredited for Litigation (BVAL), was first offered in 1998 and is designed for "experienced business appraisers who demonstrate their ability to competently present expert testimony which supports their objective conclusion of value." (www.instbusapp.org/certify.asp)

The American Society of Appraisers, formed in 1936, offers two designations, the Accredited Member (AM) and the Accredited Senior Appraiser (ASA). The AM certification is available to professionals with two years' experience in business valuations while the ASA certification is available for persons with five years' experience. Attainment of other professional certifications like the CPA, CBA or CFA shortens the experience requirement for each of these designations by one year. 
The National Association of Certified Valuation Analysts (NACVA), formed in 1991, also offers two designations. The Certified Valuation analyst (CVA) is specifically for CPAs who have passed the certification exam or have sufficient applicable experience. The Accredited Valuation analyst (AVA) is designed for professionals who are not CPAs and have completed the exam and have appropriate levels of experience or expertise.

\section{Forensic Accounting Designations}

Recent corporate scandals involving both fraudulent reporting and misappropriation of assets and the resulting regulatory changes have increased all accountants' need to be able to detect and prevent fraud. The recently released Statement of Auditing Standards (SAS ) No. 99 "Consideration of Fraud in a Financial Statement Audit" requires that auditors identify risks of material misstatements due to fraud and exercise professional skepticism when considering whether a material misstatement in the financial statements might exist as a result of fraud. While SAS No. 99 provides guidance for external auditors in detecting material fraud, obtaining additional training, certifications and continuing education in this area can be an important career step. As Toby Bishop, president of the Association of Certified Fraud Examiners notes, " Teaching future accountants about fraud and how to combat it would give those people additional tools and knowledge to enhance their performance and effectiveness throughout their careers." (Klein, 2003)

One of the most widely recognized providers of Forensic Accounting Certifications and Continuing Professional Education courses is the Association of Certified Fraud Examiners, an organization of 28,000 professionals established in 1988, which offers the Certified Fraud Examiner (CFE) designation. The CFE designation is awarded to applicants who have the proven expertise to detect, prevent, and investigate a wide range of fraudulent conduct. One unique feature of the CFE designation is that a college degree is not an absolute requirement for achieving the designation; a combination of work experience and other professional designations can substitute for formal education.

The Certified Forensic Accountant (CrFA) designation is offered by The American College of Forensic Examiners International (ACFEI), which promotes itself as the largest professional membership association representing forensic examiners. The organization is multidisciplinary in its scope, also providing certification programs in Homeland Security and Medical Investigations. The ACFEI disseminates information about forensic science through its journal, The Forensic Examiner and conferences, continuing education courses, home study courses, lectures and seminars.

The National Association of Certified Valuation Analysts (NASVA), previously discussed in the section on Business Valuation, offers two certification programs. The Certified Forensic Financial Analyst (CFFA) is designed for those individuals who support the legal community by testifying in court, generally as an expert witness. The Certified Fraud Deterrence Analyst (CFD) credential, which will be offered starting in 2003, will be designed "to provide assurance to the legal, business, advisory and CPA community the designee possess a level of experience and knowledge deemed acceptable by the Association to provide competent fraud deterrence and analytical forensic services." (www.nacva.certifications/C_cfd.html)

\section{Financial Services Designations}

\subsection{Trusts And Estates}

Tax planning is a high value-added service and while CPAs are already empowered by the IRS to render all non-litigation tax services additional opportunities for specialization exist, particularly within the estate planning area. Further, obtaining an appropriate credential gives the public comfort as to the quality of services. It may also provide opportunities for networking with professionals from other disciplines, such as law and financial planning. 
Included in this listing are credentials that allow CPAs to acquire specialized knowledge in the estate planning field. Some may be particularly well suited to CPAs because they restrict participants to those who also hold high-end credentials, like attorneys and CFPs.

The National Association of Estate Planners and Councils (NAEPC), founded in 1962, emphasizes the team approach to estate planning in its Accredited Estate Planner (AEP) credential. It brings together financial planners, tax and legal experts, insurance professionals, trust officers and others engaged in the field. Membership requires a CPA, JD, CFP or similar high-end designation.

The National Association of Financial and Estate Planning (NAFEP) was launched in 1993. It has been endorsed concerning its estate planning expertise by over 200 organizations, including Cornell University Law School. Its Certified Estate Adviser (CEA) designation requires 8-12 hours of study and a 90-minute examination.

The American Academy of Financial Management (AAFM) was established in 1995. It is aggressively expanding its scope internationally with the support of faculty from major universities in the United States and Europe, with the endorsement of the Chinese government, and with a strategic alliance with the Association to Advance Collegiate Schools of Business (AACSB), the world's foremost accrediting organization for business schools. Its Chartered Trust and Estate Planner (CTEP) requires for admission a CPA, a JD, a professional credential which requires graduate work, or an AACSB-accredited graduate degree, as well as 3 years of experience.

The Institute of Business and Finance has offered Board Certification in Estate Planning (BCE) since 1996. Among its features is a mandatory case study.

The National Institute for Certified Estate Planners' (NICEP) Certified Estate Planner (CEP) credential requires study in taxation, asset protection, insurance, trusts and several other areas related to estate planning.

The National Institute for Excellence in Professional Education (NIEPE) has offered the Certified Specialist in Estate Planning (CSEP) designation since 1998. Admission requires the accumulation of 40 "points," which can be obtained through a variety of means. A CPA with the baccalaureate degree would automatically qualify, having earned 20 points for four years of college and 20 points for holding a CPA license.

\subsection{Financial Planning And Investment Services}

Although accountants have always been asked investment advice from their clients, state professional regulations barred CPAs from accepting commissions for this advice until 1988 when the AICPA dropped the restriction from its code of ethics. With the change, many accounting firms have added financial planning and investment services to the traditional auditing and tax services.

Discussions with clients on financial planning issues are a natural part of the tax preparation and planning that CPAs have always performed. The typical long-term CPA-client relationship generates trust by the client in the CPA's opinions on financial matters. To maintain this trust, CPAs should train as rigorously for the new services as they did in accounting, auditing and tax to obtain the CPA designation. This rigor can best be demonstrated by obtaining a recognized certification in financial planning.

Four designations meet the criterion for rigor discussed above. The Personal Financial Specialist (PFS) sponsored by the AICPA, the Certified Financial Planner (CFP) sponsored by the Certified Financial Planner Board of Standards, Chartered Financial Analyst (CFA) sponsored by the Association for Investment Management and Research, and the Chartered Financial Consultant (ChFC) sponsored by The American College.

The AICPA first offered the Personal Financial Services (PFS) designation in 1987 for CPAs and AICPA members who wish to practice financial planning. It requires a six-hour exam and practical and academic work experience. 
The Certified Financial Planner Board of Standards is a non-profit organization established in 1985 to regulate the practice of financial planning by persons holding the board's Certified Financial Planner (CFP) designation. The designation requires completion of a board-registered program or a recognized substitute, passing a ten-hour examination and having appropriate work experience.

The Association for Investment Management and Research (AIMR) was founded in 1990 through the merger of the Financial Analysts Federation (FAF) and the Institute of Chartered Financial Analysts (ICFA). It is an international non-profit organization whose mission is to educate and provide a code of conduct for its financial management membership. It administers the Chartered Financial Analyst (CFA) designation, which was first awarded in 1963. The designation has 50,000 holders and requires passing one six-hour and two three-hour examinations. While the AIMR sponsors a professional development program, CFAs are not required to participate. Nonetheless, this designation is included because it has a large number of holders.

The American College administers the Chartered Financial Consultant (ChFC) designation. It was first awarded in 1982 and has 38,000 holders. It requires completion of eight courses, each with a two-hour examination, and three years of work experience. Holders active in certain practice areas are required to obtain $30 \mathrm{CPE}$ credits every two years. The program is designed to train the planner in the preparation of comprehensive financial plans.

Financial planners wishing to sell securities must obtain a national license from the National Association of Security Dealers (NASD) that was created in 1938 by the Maloney Act Amendments to the Security and Exchange Act of 1934. NASD is charged with regulating the securities industry and as such administers national licensing examinations.

The two most common licenses financial planners obtain are the Series 6 and the Series 7 licenses. The series 6 license is required to sell mutual funds, variable annuities and insurance products. The series 7 license allows the selling of products from Series 6 plus the holder can sell individual securities. The appropriate series' examination must be passed to demonstrate acceptable knowledge in the given area.

In addition to the federal license most states license financial planners. Passing the series 63 examination is required to become a dealer/broker while the series 65 examination is required to register as an investment advisor.

There are a number of other licenses offered by NASD that a financial planer may wish to obtain. To find more information on these licenses go to the NASD website at www.nasdr.com.

\subsection{Elder Care}

Another emerging area identified by the Vision Project is eldercare assurance services. (AICPA, Vision Project White Paper) The population is rapidly aging and professionals able to ensure the comprehensive well being of the elderly will likely find many opportunities to prosper. The focus of this service is on measuring how effectively various professionals can meet client-established goals that embrace the tax, financial, estate planning, medical and other aspects of elders' lives.

The Society of Certified Senior Advisors created the Certified Senior Adviser (CSA) in 1996. The Center for Senior Studies created the Certified Senior Specialist (CSS) in 1998. Both require in-depth coursework in the various areas indicated above.

\subsection{Divorce}

There can be little doubt that divorce-related services have a wide market. Given the near-50\% incidence of divorce and the financial and personal disasters that can accompany marital dissolution, many individuals would be attracted by a credential that stands for quality pre-divorce and divorce litigation support services.

The College for Divorce Specialists has offered the Certified Divorce Specialist (CDS) credential since 2002, although its predecessor dates back to 1993. Membership is restricted to attorneys, CPAs, CFPs, and a few 
other high-end designation holders, or to those with at least five years of significant experience in divorce matters. Among other things, the curriculum covers both multi-state and multi-national divorce matters.

\section{Information Technology Designations}

The AICPA Vision Project identified the information technology area as providing excellent opportunities for CPAs. (AICPA, Vision Project) Among the services that properly trained CPAs can offer are expertise in information technology security, the delivery of turn-key information technology systems, and consulting in the growing internet-based business-to-business (B-2-B) and business-to-consumer (B-2-C) distribution channels.

Two information technology designations have been identified as being appropriate for accountants desiring to specialize in information technology security and systems. The first is the Certified Information Technology Professional (CITP) offered by the AICPA. The second is the Certified Information Systems Auditor (CISA) sponsored by the Information Systems and Control Association.

The CITP has been in existence for two years and has 500 holders. The holder must be a member of the AICPA and must accumulate 100 "points" based on work experience, life-long learning, and an optional examination.

The CISA designation was started in 1978 to recognize the holder's status as a qualified computer auditor, control and/or security professional. The designation is currently held by 30,000 people and requires passing a fourhour examination, having relevant work experience and obtaining 120 hours of CPE every three years.

E-commerce is rapidly expanding within the global economy, and CPAs can participate in this growth as B-2-B and B-2-C consultants. The Institute of Certified E-Commerce Consultants was founded in 1996 by university professors and Internet professionals. Its focus is on e-business as a channel of distribution. The Institute's Certified E-Commerce Consultant (CEC) is endorsed by the World E-Commerce Forum and the American E-Commerce Association. It has strategic alliances with many universities including Stanford, Yale, Purdue and USC; and it has members in over 70 countries.

\section{Insolvency And Restructuring Designations}

The Association of Insolvency and Restructuring Advisors (AIRA) established the Certified Insolvency and Reorganization Adviser (CIRA) designation in 1992. A CPA, CMA or equivalent credential is required for membership. The designation is used by professionals who assist troubled companies, who work with bankruptcy trustees and debtors-in-possession, and who help attorneys in litigation involving insolvency matters. (Kahan, 1998) Whether economic times are good or bad, it seems that the number of bankruptcy filings rise almost unabated and make this specialized area an attractive opportunity for CPAs. (http://www.bankruptcyaction.com/USbankstats.htm)

\section{References}

1. American Institute of Certified Public Accountants (AICPA). (n.d.). "Vision Project: 2011 and Beyond", Retrieved May 21, 2003 from http://www.cpavision.org/vision.htm.

2. American Institute of Certified Public Accountants (AICPA). (n.d.). "Vision Project White Paper: Assurance Services", Retrieved May 21, 2003 from http://www.cpavision.org/vision.htm.

3. Gaffen, Gregg S. (2002). "Guidance for the CPA entering the business valuation profession", Ohio CPA Journal, 61, 22-31.

4. $\quad$ Kahan, Stuart. (1998). "The Rewards of Insolvency”, The Practical Accountant, 31, 64-65.

5. Klein, Melissa. (2003,). "New Environment drives up demand for fraud CPE", Accounting Today, March 17, pp.3, 53. 


\section{Insert}

Article 307 Table 1

(Excel Table)

Here 

Notes 